\title{
The Khuff Formation in the Middle East: New Insight into Regional Stratigraphy and Palaeoenvironmental Reconstruction using Bio- assemblages and Facies Analysis
}

\author{
Jérémie Gaillot (Total), Aurélien Virgone (Total), Bruno Caline (Total \\ $<$ bruno.caline@total.com>), Grégory Frébourg (University of Geneva, Switzerland) and \\ Franck Gisquet (University of Provence, France)
}

A multidisciplinary synthesis of outcrop and subsurface data of the carbonates and evaporites of the Late Permian Khuff Formation was carried out in order to constrain the spatial and stratigraphic distribution of the depositional facies.

A robust biostratigraphic framework was built based on detailed description of algaforaminiferal biotic content (Gaillot, 2006). The material studied includes 6,000 thin sections prepared from 16 cored wells in Iran, Qatar, Abu Dhabi and from four outcrop rock samples in Iran and southeastern Turkey. Comparison of microfossil distribution, mainly calcareous algae and foraminifers, within this large dataset has resulted in subdivision of the Middle and Late Permian Khuff deposits into eight units. Each unit shows a turnover level corresponding to significant reshaping of biotic assemblages characterized by higher biodiversity, which preferably occurs during the maximum accommodation phase of cycles before being isolated again during phase of lower accommodation in protected intra-shelf 'lows' (Figure 1). This suggests that the periods of higher biodiversity likely correspond to the flattest configurations of the Khuff platform, when the intra-shelf 'lows' are filled, and when extensive lateral shifts of biofacies are favored.

The Permian-Triassic transition is well constrained by sedimentological, biostratigraphical, geochemical and wireline log data over the studied area. The succession of events suggests that the platform top experienced a major flooding event immediately before its near complete emersion. During the latest Permian, the assemblages progressively migrated towards palaeohighs before the final drowning and demise of the green algal margin reef in the Zagros area. The rapid progradation of restricted facies belts seaward during the early transgression through the Permian/Triassic boundary allowed the microbial communities to overcome the latest Palaeozoic algal/foraminiferal assemblages in the studied area.

The detailed sedimentological description of the cores and outcrops has resulted in definition and characterization of 16 main depositional facies (Insalaco et al., 2006). These facies were used to interpret the depositional environment at a regional scale and for correlation of the Upper Khuff depositional systems across the entire epeiric shelf. Conceptual depositional models have been constructed for the main stratigraphic intervals after integration of the facies succession and biostratigraphic interpretations. These models evidence significant changes in platform type, subsidence regime, geometry, facies organization and climate within the four cycles (K4 to K1) of the Upper Khuff reservoir interval. The correlation and stratigraphic analysis suggests that the major stratigraphic trends and large-scale stratigraphic architecture are relatively isopacheous at production scale due to the almost flat platform geometry. At a larger scale, significant changes in thickness occur: either thickening towards palaeodepocentres or thinning with onlap towards palaeohighs. Palaeoecological results show that the structurally controlled palaeohighs are successively drowned and that the system evolves progressively from a rimmed platform towards an almost uniformly flat ramp. 
The major oolite units developed within high-subsiding areas by sediment volume funneling, mainly during the late Wuchiapingian (upper K4 Sequence) and Early Triassic (K2 Sequence). Recent core examination has further constrained the interpretation of the uppermost $\mathrm{K} 4$ and the lowermost $\mathrm{K} 3$ intervals. Thin section examination under cathodoluminescence microscopy has evidenced a major subaerial exposure surface characterizing the sequence boundary of K4 Sequence. In addition, an oomouldic interval deposited at the top of the $\mathrm{K} 4$ unit has been recently re-interpreted based on detailed sedimentological core description using CT scanner imaging (Frébourg et al., 2010). Conversely to initial interpretation, the oomouldic interval does not show unequivocal criteria indicating marine deposition. Sedimentary and diagenetic features, which include pinstripe lamination, cross-stratification with angles $>15^{\circ}$ and rhizolite traces, reveal aeolian deposition (Figure 2).

The depositional and stratigraphic interpretation of this multidisciplinary study has provided a consistent sedimentological and sequence-stratigraphic framework for the Upper Khuff in the Arabian Plate area. This coherent geological framework is used for regional exploration as well as prospect evaluation and field development. This framework has been also applied to reservoir-scale diagenetic and reservoir quality studies.

\section{References}

Frébourg, G., E. Davaud, A. Virgone, J. Gaillot and M. Kamali 2010. Discovery of an eolianite in the Upper Dalan Member, South Pars field, Iran. Journal of Petroleum Geology, v. 33, p. 141-154.

Gaillot, J. 2006. The late Permian-early Triassic Khuff Formation in the Middle-East: sequence biostratigraphy and palaeoenvironments by means of calcareous algae and foraminifers, unpublished $\mathrm{PhD}$, univ. Lille, France, 3 volumes, $213 \mathrm{p}$.

Insalaco E., A. Virgone, B. Courme, J. Gaillot, M. Kamali, A. Moallemi, M. Lotfpour and S. Monibi 2006. Upper Dalan Member and Kangan Formation between the Zagros Mountains and offshore Fars, Iran: Depositional system, biostratigraphy and stratigraphic architecture, GeoArabia, v. 11, no. 2, p. 75-176. 


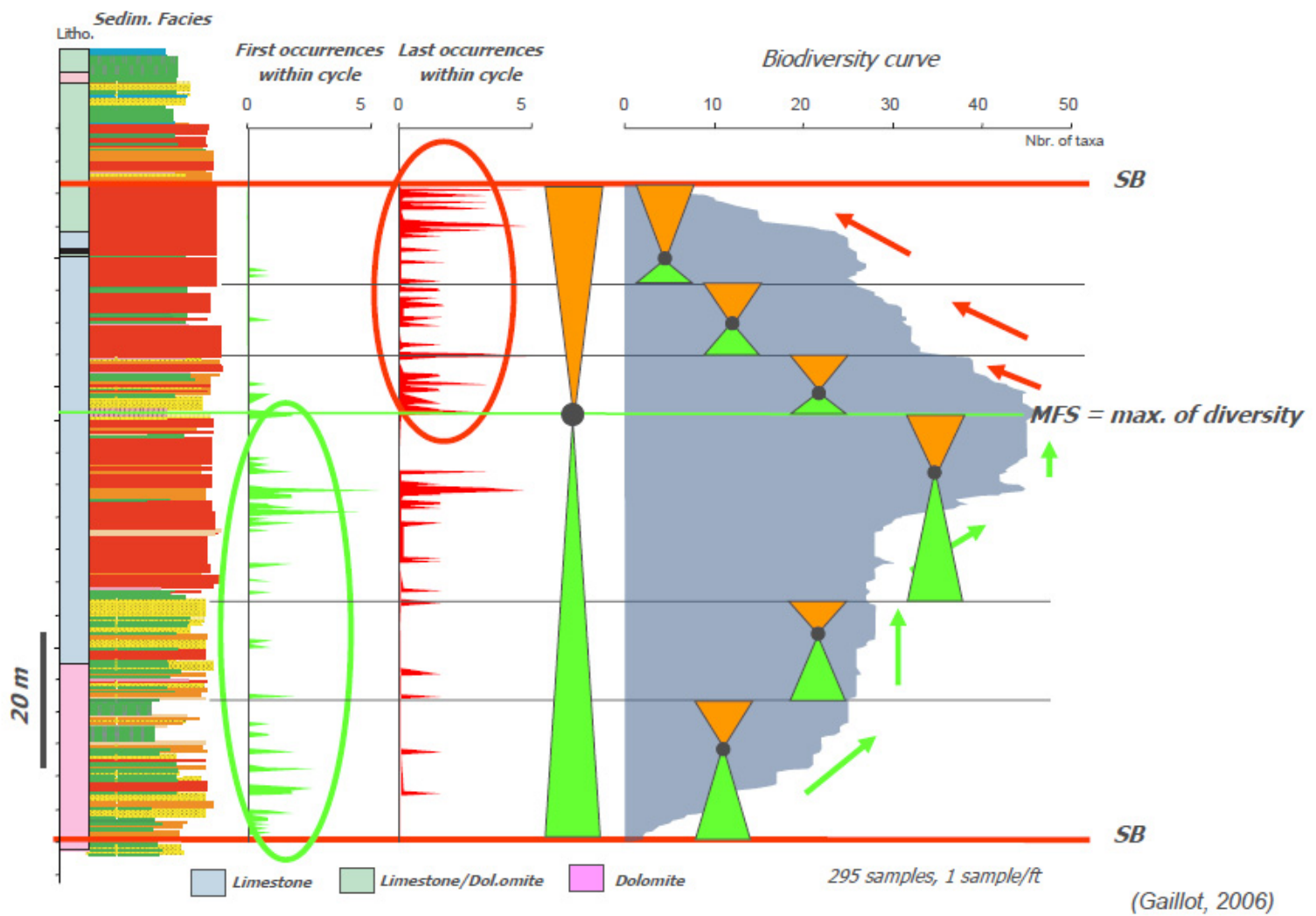

Figure 1 - Stratigraphic cycle based on biodiversity curve: example of KS4 sequence 


\section{EAGE}
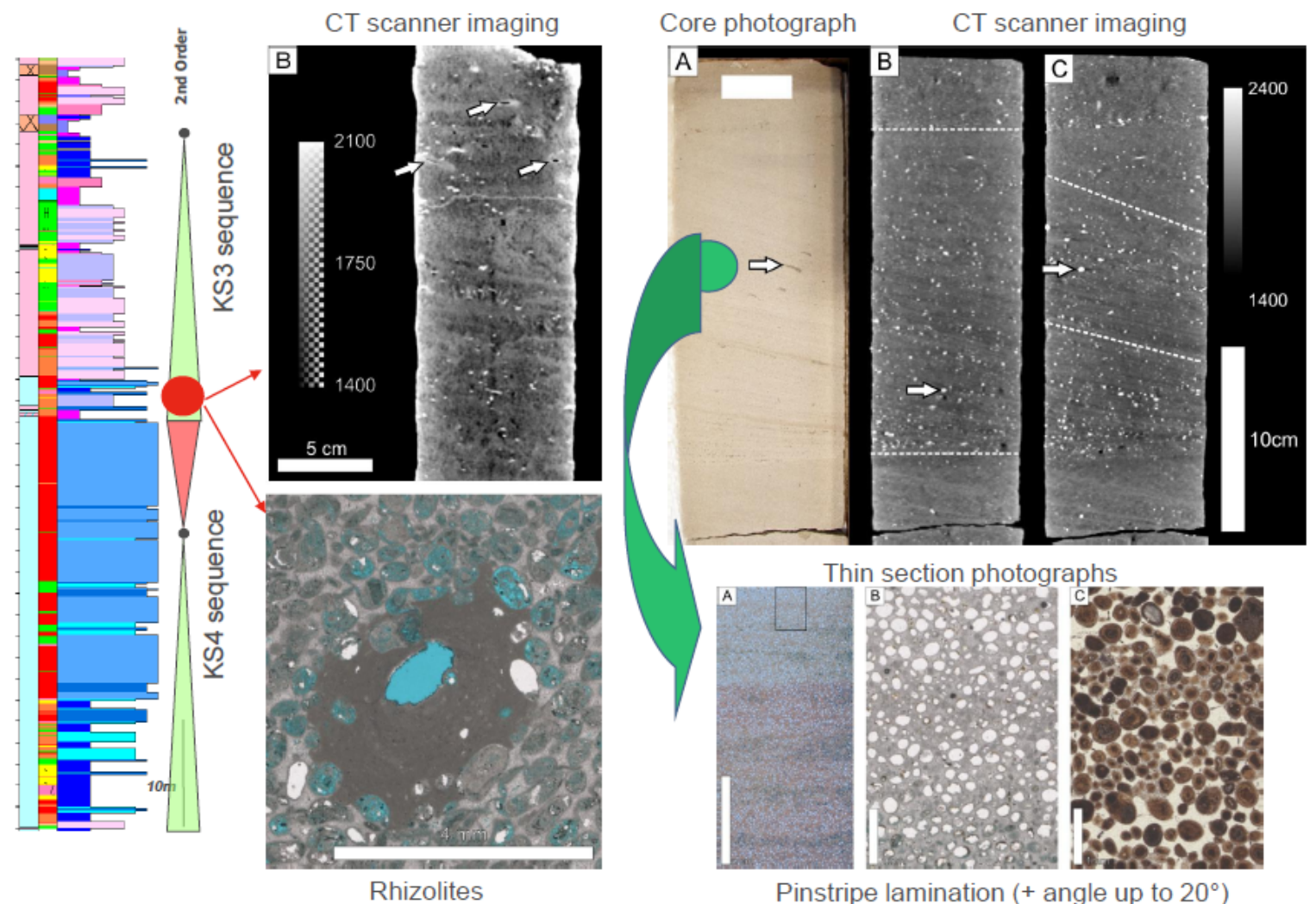

Pinstripe lamination (+ angle up to $20^{\circ}$ )

Figure 2 - Eolianite facies deposited above top KS4 sequence

(Frébourg et al., 2010) 